\title{
Tactical behavior in soccer small-sided games: influence of team composition criteria
}

\section{Comportamento tático em pequenos jogos no futebol: influência do critério de composição das equipes}

Gibson Moreira Praça ${ }^{1}$

Juan Carlos Pérez Morales'

Pedro Emílio Drumond Moreira ${ }^{1}$

Gustavo Henrique Cunha Peixoto ${ }^{2}$

Sarah Teles Bredt²

Mauro Heleno Chagas ${ }^{2}$

Israel Teoldo ${ }^{3}$

Pablo Juan Greco ${ }^{1}$

Abstract - This study aimed to compare the tactical behavior of young soccer players during small-sided games played with team composition criteria based on procedural tactical knowledge, aerobic power and speed performance. Eighteen male soccer players played 3vs.3 small-sided games with teams balanced according to players' performance on Sprint Test, Yo-Yo Intermittent Recovery Test and the field test of the System of Tactical Assessment in Soccer. Data related to the incidence of tactical principles were analyzed through the proportions chi-square test with Bonferroni's correction. One-way ANOVA was used to compare players' offensive and defensive tactical performance. Results showed different incidence of offensive and defensive tactical principles in games with different teams' composition criteria. It has also been shown a higher defensive performance when the teams' composition criteria was based on players' procedural tactical knowledge.

Key words: Physical education and training; Soccer; Task performance and analysis.

Resumo - Este estudo objetivou comparar o comportamento tático de jovens atletas de futebol durante pequenos jogos com critérios de composição das equipes baseados no conhecimento tático processual, capacidade aeróbica e desempenho de velocidade. Dezoito jogadores participaram de pequenos jogos na configuraçẫo 3 vs. 3 com equipes equilibradas de acordo com o desempenho no Teste de Sprint, no Yo-Yo Intermittent Recovery Test e no teste de campo do Sistema de Avaliação Tática no Futebol - FUT-SAT. Analisaram-se os dados relativos à incidência dos princípios táticos por meio do teste de qui-quadrado de proporçôes e conduziram-se comparaçôes pareadas a partir da correção de Bonferroni. Para a comparação do desempenho tático ofensivo e defensivo recorreu-se à ANOVA one-way. Resultados apontaram diferenças na incidência de princípios táticos ofensivos e defensivos a partir da utilização dos três diferentes critérios de composição das equipes. Observou-se ainda maior desempenho tático defensivo a partir da composição das equipes baseada no conhecimento tático processual dos atletas

Palavras-chave: Análise de desempenho de tarefas; Educação Física e Treinamento; Futebol.
1 Universidade Federal de Minas Gerais. Escola de Educação Física, Fisioterapia e Terapia Ocupacional. Departamento de Esportes. Centro de Estudos em Cognição e Ação. Belo Horizonte, MG. Brasil.

\section{Universidade Federal de Minas} Gerais. Escola de Educação Física, Fisioterapia e Terapia Ocupacional. Departamento de Esportes. Laboratório de Biomecânica. Belo Horizonte, MG. Brasil.

3 Universidade Federal de Viçosa. Departamento de Educação Física. Núcleo de Pesquisa e Estudos em Futebol. Viçosa, MG. Brasil.

Received: 28 November 2016 Accepted: 08 June 2017

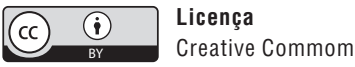




\section{INTRODUCTION}

The small-sided games (SSG) are a specific means of training in soccer and allows the development of abilities inherent to soccer performance ${ }^{1}$ in a tactical-situational context similar to the formal game ${ }^{2,3}$. The investigation on the tactical behaviors present in different SSG configurations has developed in the last decades and has lead to a better understanding of the effects of altering different SSG characteristics on these behaviors (e.g. field size, number of players, aim of the game) as a consequence of the growing use of some assessment tools, such as the System of Tactical Assessment in Soccer (FUT-SAT) ${ }^{4}$. Consequently, coaches have increased their possibilities of adjusting these SSG configurations to the objectives of the teaching-learning process and training sessions ${ }^{5}$.

The development of tactical abilities in the SSG are related to a cooperation-opposition context, evidenced by the two confronting teams, similarly to the formal game ${ }^{6}$. It could be suggested that the alteration of players' characteristics during SSG occurs based on a team composition criterion. Team composition criterion can be defined as the variable used to split players into balanced teams in order to play the SSG. Criteria such as players' original position ${ }^{7}$, aerobic power ${ }^{8}$, and technical skills ${ }^{8}$ have been described in the literature and used for teams' composition in SSG. Köklü et al. ${ }^{8}$ observed that teams balanced for aerobic power presented a higher distance covered in higher intensities and higher mean heart rate, which shows the influence of teams' composition in players' physiological and physical responses during SSG. Besides aerobic power, speed performance is a factor that influences players' soccer performance once it requires high velocities to be reached in order to overcome opponents for ball possession?. However, speed performance has not been used as a team composition criterion in the literature.

On the other hand, considering the unpredictability, randomness, and complexity inherent to soccer game ${ }^{10}$, players' knowledge structures are relevant determinants of soccer performance ${ }^{11}$. Thus, athletes' procedural tactical knowledge (PTK) can be seen as an alternative for teams' composition during SSG. In this sense, it could be suggested that athletes' knowledge on tactical principles is an important means of assessment of tactical knowledge because these principles are crucial to the understanding of games' logic. However, no study investigated the influence of tactical ability as a team composition criterion on performance of young athletes. This gap limits the utilization of SSG in training process.

The incipience of the investigation on individuals' abilities as teams' composition criteria in SSG is reflected in the heterogeneity of protocols among studies. However, clear justifications for the selection of a teams' composition criterion are still scarce, which limits not only the investigation (and interpretation of previous studies' results) but also training practice with soccer SSG. Although Köklü et al. ${ }^{8}$ suggested the use of aerobic power as a team composition criterion with the aim of increasing 
SSG physiological demand, there is no investigation on the use of tactical ability as a team composition criterion - compared to physical abilities, as previously show in the literature. Besides that, literature presents no information on the effect of different team composition criteria on players' tactical responses, which limits the use of SSG as a means of training of tactical abilities in soccer. In this context, this study aimed to analyze the influence of the teams' composition criteria tactical knowledge, aerobic power, and speed performance on the tactical behavior of young soccer players during 3vs.3 SSG.

\section{METHODOLOGICAL PROCEDURES}

\section{Participants}

This study has been approved by the Research Ethics Committee of the Federal University of Minas Gerais registered under the protocol number CAE 51011915.9.0000.5149. Eighteen male soccer athletes from a national team (six defenders, six forwards and six midfielders) aged between 16 and 17 took part in the study. All participants had at least five years of practice. Before the beginning of data collection, athletes and their legal guardians were explained about all the research procedures and gave their informed consent.

\section{Procedures}

At first, athletes' were assessed for procedural tactical knowledge (FUTSAT), aerobic power (Yo-Yo Intermittent Recovery Test Level 2) and speed performance (20 meters sprint). All tests were carried out during the first week, separated by 48 hours.

After these tests, the 18 athletes were classified from $1^{\text {st }}$ to $6^{\text {th }}$ among each playing position according to the different variables (FUT-SAT, aerobic power and speed performance) used for composing balanced teams (Box 1). Then, they were divided into 6 teams (A, B, C, D, E, and F) of 3 players each.

In order to minimize the influence of changing opponents' level on the tactical behaviors, teams $\mathrm{A}, \mathrm{B}$, and $\mathrm{C}$ did not play against teams $\mathrm{D}, \mathrm{E}$ and $\mathrm{F}$ in any protocol. Therefore, there has been a total of 6 different games in each protocol $(\mathrm{AxB}, \mathrm{AxC}, \mathrm{BxC}, \mathrm{DxE}, \mathrm{DxF}$, and $\mathrm{ExF})$.

Box 1. Players distribution into groups according to the teams' composition criteria and players' individual abilities.

\begin{tabular}{|c|c|c|c|c|c|c|c|c|c|}
\hline \multirow{2}{*}{ Teams } & \multicolumn{3}{|c|}{ Tactical Knowledge } & \multicolumn{3}{|c|}{ Aerobic Power } & \multicolumn{3}{|c|}{ Speed Performance } \\
\hline & Defender & Midfielder & Forward & Defender & Midfielder & Forward & Defender & Midfielder & Forward \\
\hline Team A & $\mathrm{D}^{1}$ & $\mathrm{M}^{3}$ & $F^{2}$ & $\mathrm{D}^{1}$ & $\mathrm{M}^{3}$ & $A^{2}$ & $\mathrm{D}^{1}$ & $\mathrm{M}^{3}$ & $F^{2}$ \\
\hline Team B & $D^{2}$ & $\mathrm{M}^{1}$ & $F^{3}$ & $D^{2}$ & $M^{1}$ & $A^{3}$ & $D^{2}$ & $M^{1}$ & $F^{3}$ \\
\hline Team C & $D^{3}$ & $\mathrm{M}^{2}$ & $\mathrm{~F}^{1}$ & $D^{3}$ & $\mathrm{M}^{2}$ & $A^{1}$ & $D^{3}$ & $\mathrm{M}^{2}$ & $F^{1}$ \\
\hline Team D & $D^{4}$ & $\mathrm{M}^{6}$ & $F^{5}$ & $D^{4}$ & $\mathrm{M}^{6}$ & $A^{5}$ & $D^{4}$ & $M^{6}$ & $\mathrm{~F}^{5}$ \\
\hline Team E & $\mathrm{D}^{5}$ & $\mathrm{M}^{4}$ & $\mathrm{~F}^{6}$ & $\mathrm{D}^{5}$ & $\mathrm{M}^{4}$ & $A^{6}$ & $D^{5}$ & $M^{4}$ & $F^{6}$ \\
\hline Team F & $D^{6}$ & $M^{5}$ & $\mathrm{~F}^{4}$ & $D^{6}$ & $M^{5}$ & $A^{4}$ & $D^{6}$ & $M^{5}$ & $\mathrm{~F}^{4}$ \\
\hline
\end{tabular}

Note: Playing positions: $D=$ Defender; $M=$ Midfielder; $F=$ forward. Superscript numbers indicate players' classification in the ranking of athletes of the same playing position in each test used to for teams' composition. 
Each data collection session began with a 10-minute warm-up activity that consisted of actions with and without the ball (without opposition) and typical soccer movements. Each game comprised two 4-minute bouts of 3vs.3 SSG interspersed with 4-minute passive recovery. Field size was $36 \times 27$ meters with goals sized $5 \times 2$ meters, as reported in previous studies ${ }^{12}$. All formal game rules were used, including offside.

\section{Independent Variable: Team Composition Criterion Based on Tactical Knowledge}

Players' procedural tactical knowledge was assessed through the System of Tactical Assessment in Soccer (FUT-SAT) ${ }^{4}$. This field test consists of a 4-minute $3 \mathrm{vs} .3$ game played in a field area of $36 \times 27$ meters with all formal game rules. The test was filmed for later analysis. For further information about the FUT-SAT protocol see Teoldo et al. ${ }^{3}$. The percentage of positive tactical principles was calculated ((total number of positive offensive actions + total number of positive defensive actions) / (total number of offensive actions + total number of defensive actions)) based on the observation protocol.

\section{Independent Variable: Team Composition Criterion Based on Aerobic Power}

The Yo-Yo Intermittent Recovery Test Level 2 - YIRT2 $-{ }^{13}$ was used to assess athletes' aerobic power. This test has been shown to be reliable ${ }^{14,15}$ and is an important field tool for aerobic power assessment of soccer players because of its low cost and high specificity ${ }^{14,16}$.

The test area for each participant consists of a 20x2 (length $\mathrm{x}$ width) straight lane with a 5 -meters recovery area. The test protocol comprises several 40 meters $(20+20)$ runs with progressively increased velocities controlled by sound signals. Between each run participants have a $10-$ seconds interval to recover. The test ends when participants fail to reach the finish line at the same time of the sound signals twice.

\section{Independent Variable: Team Composition Criterion Based on Speed Performance}

The 20 meters sprint was used to assess speed performance. Athletes performed three 20 meters sprints with three minutes of passive recovery between them ${ }^{9}$. The best trial was considered for analysis. Two infrared photoelectrical cells (photocells) (Matsport timing BTS, Seyssinet, France) were positioned 20 meters apart to register the time spent to cover the 20 meters. Before the test, athletes were positioned before the first pair of photocells with the preferred foot just behind the start line, in a static comfortable position for running. There was no sonorous stimulus for test to begin and athletes could start the test whenever they considered appropriate. These procedures have been used in previous studies in soccer ${ }^{9}$.

\section{Dependent variable: tactical behavior}

The System of Tactical Assessment in Soccer (FUT-SAT) was used to assess 
the tactical behaviors related to the Fundamental Tactical Principles ${ }^{4}$. The SSG bouts were filmed and then analyzed to establish the incidence of the fundamental offensive and defensive tactical principles among players. The percentage of positive offensive and defensive tactical principles were also calculated through the ratio between the number of positive tactical principles (offensive or defensive) and the total number of principles (offensive or defensive). This percentage was considered a measurement for the quality of the tactical actions in the game. The same tactical principles used as teams' composition criterion were also used as dependent variable in the present study.

\section{Data analysis}

The incidence of the fundamental tactical principles in the 3vs.3 SSG played using the different teams' composition criteria were compared using the proportion chi-square test and Bonferroni's post-hoc for repeated measures. The $\omega$ effect size was calculated as reported in the literature ${ }^{17}$ and classified as small $(\omega<0,1$, or $1 \%$ of total variance), medium $(0,1<\omega$ $<0,3$, or $9 \%$ of total variance) or large $(\omega>0.5 \text {, or } 25 \% \text { of total variance })^{17}$.

Offensive and defensive tactical performances were compared using an ANOVA one-way with repeated measures. The partial $h^{2}$ effect size was calculated as recommended in the literature ${ }^{18,19}$ and classified as "no effect" $\left(h^{2}<0,04\right)$, "minimum effect" $\left(0,04<h^{2}<0,25\right)$, "moderate effect" $\left(0,25<h^{2}<0,64\right)$, and "strong effect" $\left(h^{2}{ }_{p}>0,64\right)^{20}$.

All statistical analyses (except for $\omega$ effect size - software Microsoft Excel for Windows version 2013) were carried out using the statistical package SPSS (SPSS Version 20.0 for Windows, SPSS Inc., Chicago, IL, USA). The significance level was set at $5 \%$ for all analyses.

\section{Data reliability}

Inter and intra-observer agreements were verified for experts' observations of the tactical principles during the SSG. In this sense, $11 \%$ of the SSG bouts ${ }^{21}$ ( 4 bouts out of 36 ) were reevaluated after 21 days ${ }^{18}$ as recommended in the literature. The Cohen Kappa coefficient and its standard error (SE) were calculated for all the fundamental tactical principles - offensive and defensive. Values above $0,879(\mathrm{SE}=0,013)$ and $0,863(\mathrm{SE}=0,013)$ for intra and inter-observer agreements, respectively, indicated high agreement ${ }^{22}$.

\section{RESULTS}

Data related to tactical behavior (offensive and defensive tactical principles) are expressed as the total incidence of each principle in each team composition criteria. Data related to the quality of tactical actions are expressed as the percentage of positive principles (offensive and defensive). The number of tactical actions per player in each bout corresponded to 14965 $( \pm 69,2)$. SSG played by teams' composition based on tactical knowledge presented higher incidence of offensive $\left(c^{2}=7,966 ; p=0,018\right.$; medium effect $)$ and defensive $\left(c^{2}=43,136 ; p=0,001 ;\right.$ medium effect $)$ coverage compared to 
SSG played by teams balanced for aerobic power. There was also a higher incidence of delay $\left(c^{2}=9,626 ; p=0,008\right.$; medium effect $)$ and concentration $\left(c^{2}=6,901 ; p=0,032\right.$; medium effect $)$ when the SSG were played by teams composed by the aerobic power criterion than when teams were composed by the speed performance criterion. Moreover, there was a higher incidence of width and length with ball $\left(c^{2}=6,323 ; p=0,042\right.$; medium effect $)$ when teams were composed based on speed performance compared to tactical knowledge. Therefore, the influence of teams' composition criteria on the tactical behaviors during SSG was confirmed by the results of this study.

Finally, in SSG played by teams balanced for the tactical knowledge criterion it was observed a higher defensive tactical performance $(F=14,778$; $p=0,001$; minimum effect $)$ compared to the other two criteria $(F=12,678$; $p=0,002 ;$ minimum effect).

Table 1. Influence of teams' composition criteria on tactical behavior during SSG.

\begin{tabular}{|c|c|c|c|c|c|c|}
\hline Variable & Speed performance ${ }^{a}$ & Aerobic Power ${ }^{b}$ & Tactical Knowledge $^{c}$ & $p$-value & PostHoc & Effect Size \\
\hline \multicolumn{7}{|c|}{ Offensive Principles } \\
\hline Penetration & 321 & 290 & 314 & 0,424 & & 0,0891 \\
\hline Offensive Coverage & 453 & 420 & 505 & $0,018^{*}$ & $c>b$ & 0,1924 \\
\hline Width and length (without ball) & 738 & 810 & 765 & 0,180 & & 0,1261 \\
\hline Width and length (with ball) & 118 & 96 & 83 & $0,042^{*}$ & $a>c$ & 0,1711 \\
\hline Depth Mobility & 172 & 155 & 161 & 0,633 & & 0,0650 \\
\hline Offensive Unity & 575 & 635 & 525 & $0,005^{*}$ & $b>c$ & 0,2204 \\
\hline \multicolumn{7}{|c|}{ Defensive Principles } \\
\hline Delay & 428 & 520 & 454 & $0,008^{*}$ & $b>a$ & 0,2111 \\
\hline Defensive Coverage & 221 & 111 & 219 & $0,001^{*}$ & $a / c>b$ & 0,4469 \\
\hline Defensive Balance & 361 & 357 & 343 & 0,777 & & 0,0484 \\
\hline Recovery Balance & 241 & 246 & 223 & 0,539 & & 0,0757 \\
\hline Concentration & 251 & 312 & 272 & $0,032^{*}$ & $b>a$ & 0,1787 \\
\hline Defensive Unity & 1093 & 1096 & 1081 & 0,944 & & 0,3406 \\
\hline \multicolumn{7}{|c|}{ Percentage of positive principles } \\
\hline Offensive tactical performance & 0,761 & 0,739 & 0,744 & 0,391 & & 0,013 \\
\hline Defensive tactical performance & 0,594 & 0,559 & 0,700 & $0,001^{*}$ & $c>a / b$ & 0,139 \\
\hline
\end{tabular}

* Significant difference $(p<0,05)$ a,b,c: different when compared to compositions based on speed performance, aerobic power, and tactical knowledge, respectively.

\section{DISCUSSION}

This study aimed to analyze the influence of different teams' composition criteria on tactical behavior of young soccer players during 3vs.3 SSG. It has been observed that the tactical knowledge criterion induced an increase the defensive tactical performance, as well as behavioral differences related to the incidence of certain fundamental tactical principles.

The understanding that players' behavior during the game - formal game as well as small-sided games - is influenced by the cooperation established among teammates ${ }^{23}$ supports the concerning about the different teams' composition criteria that can be adopted. In this study, the improvement of tactical performance presented in the situations when teams were 
balanced for tactical knowledge indicates that the cooperation patterns established among teammates with the same tactical level, as well as the confrontation against opponents with the same level of tactical knowledge leads to the appearance of better decisions. This decision-making, evaluated by the execution of the tactical principles, reflects players' understanding of the time and space management $\operatorname{logic}^{24}$. In this sense, time and space management reflects the interactions among players, once the cooperationopposition characteristics during the game ${ }^{25}$ requires behavioral adjustments depending on teammates and opponents' actions. Therefore, when athletes cooperate/confront other athletes of similar tactical level, the establishment of the interpersonal relationships is facilitated during the game and, consequently, a better tactical performance is expected - as shown in this study.

Besides that, considering that the tactical behavior results from an intentional action directed towards a goal in a given environment ${ }^{26}$, it presented some specificities related to the teams' composition criterion adopted. At this point, a higher incidence of offensive and defensive coverage was observed in SSG oriented by the tactical knowledge criteria compared to the SSG oriented by aerobic power. There was also a higher incidence of defensive coverage when teams were composed based on speed performance compared to aerobic power. These results suggest that the coverage actions represent the actions of teammates/opponents that aim to support the player with the ball - offensive - or the player defending the one with the ball - defensive - which are, therefore, strongly influenced by teammates and opponents' behaviors ${ }^{24,27}$. Thus, the higher incidence of coverage actions reported in the SSG played by teams of similar tactical knowledge reflects a better generation of options and decisions, which allows players to constantly offer support to players directly involved with the ball - penetration/delay dyad.

On the other hand, this study showed a higher incidence of concentration and offensive unity actions in the SSG played by teams balanced for aerobic power and higher incidence of width and length with ball and defensive coverage in the SSG played by teams balanced for speed performance, reinforcing the behavioral specificities related to each teams' composition criterion. Therefore, team composition based on aerobic power increases the number of offensive (offensive unity) and defensive (concentration) actions out of game center and behind the line of the ball. This suggests that players wait for opponents mistakes in order to regain ball possession or progress along playing field, either setting an organized offense (offensive action) or orientating players in offense (defensive action) to a given direction - frequently the sides of the pitch. The higher incidence of mobility actions - even though it was not significant - in the SSG played by teams composition based on speed performance compared to aerobic power reinforces this rationale. However, the non-existence of previous studies on the relationships between tactical behavior and speed/ aerobic performances limits the inferences that can be made from these 
results, which suggest the need of further investigation in this area.

Once SSG are a means of training often adopted by soccer coaches and physical trainers ${ }^{28}$, the concerns about teams' composition criteria must be summated to the concerns about SSG configurations - field size, number of players per team, specific rules, and others. The results of this study suggest that the tactical knowledge as teams' composition criterion should be adopted when a higher tactical performance is sought in a certain training session. On the other hand, the adoption of the speed performance and aerobic power criteria is appropriate to achieve the specific tactical behaviors width and length with ball and delay/concentration, respectively. However, future studies with athletes of different ages and performance levels should be carried out in order to verify whether the behaviors observed in this study are present in other soccer practice contexts.

\section{CONCLUSION}

In general, we can conclude that different team composition criteria - based on aerobic power, speed performance and tactical ability - alters tactical behaviors of young players, which is evidenced by the differences in the incidence of different tactical principles. Therefore, coaches must consider SSG specificities when prescribing SSG during training sessions, in order to emphasize training of specific tactical principles only by changing team composition criterion. For example, SSG played by teams balanced for tactical ability present higher incidence of offensive and defensive coverage compared to SSG played by teams balanced for aerobic power. On the other hand, the latter presents more actions of offensive unity and concentration compared to SSG played by teams with similar tactical ability. Finally, the use of tactical ability as a team composition criterion increased tactical performance compared the other criteria. This result suggests that coaches can use this criterion with the aim of facilitate defensive tactical actions, especially in the initial phase of tactical learning, because it allows creating contexts of lower tactical demand. Conversely, in order to increase tactical demand, the results of the present study suggest the adoption of physical/physiological aspects - aerobic power and speed performance - as team composition criteria.

\section{Acknowledgements}

We thank Fundação de Amparo à Pesquisa do Estado de Minas Gerais (FAPEMIG) and Pró-reitoria de Pesquisa (PRPq) of Universidade Federal de Minas Gerais for financial support, and Clube Atlético Mineiro for helping with data collection.

\section{REFERENCES}

1. Hill-Haas S, Coutts AJ, Rowsell GJ, Dawson BT. Generic versus small-sided game training in soccer. J Sci Med Sport 2009;30(9):636-42.

2. Praça GM, Folgado H, Andrade AGP, Greco PJ. Influence of additional players on collective tactical behavior in small-sided soccer games. Rev Bras Cineantropom Desempenho Hum 2016;18(1):62-71. 
3. Praça GM, Costa CLA, Costa FF, Andrade AGP, Chagas MH, Greco PJ. Tactical behavior in soccer small-sided games: influence of tactical knowledge and numerical superiority. Journal of Physical Education 2016;27(1):e2736.

4. Teoldo I, Garganta JM, Greco PJ, Mesquita I, Maia J. System of tactical assessment in Soccer (FUT-SAT): Development and preliminary validation. Motrici 2011;7(1):69-83.

5. Clemente FM, Martins FML, Mendes RS. Periodization Based on Small-Sided Soccer Games: Theoretical Considerations. Strength Cond J 2014;36(5) 34-43.

6. Gréhaigne JF, Bouthier D. Dynamic-system analysis of opponent relationships in collective actions in soccer. J Sports Sci 1997;15(2):137-49.

7. Frencken W, Lemmink K, Delleman N, Visscher, C. Oscillations of centroid position and surface area of soccer teams in small-sided games. Eur J Sport Sci 2011;11(4):215-23.

8. Köklü Y, Ersöz, G, Alemdaroglu U, Asxcxi A, Özkan A. Physiological responses and time-motion characteristics of 4-A-side small-sided game in young soccer players: The influence of different team formation methods. J Strength Cond Res 2012;26(11):3118-23.

9. Chamari K, Hachana Y, Ahmed B, Gal O, Sghaier F, Chatard J-C, Hue O, Wisløff U. Field and laboratory testing in young elite soccer player. Br J Sports Med 2004;38:191-6.

10. Garganta J. Trends of tactical performance analysis in team sports: bridging the gap between research, training and competition. Rev Port Ciên Desp 2009;9(1):81-9.

11. Afonso J, Garganta, J, Mesquita, I. Decision-making in sports: the role of attention, anticipation and memory. Rev Bras Cineantropom Desempenho Hum 2012;14(5):592-601.

12. Praça GM, Custódio IJO, Greco PJ. Numerical superiority changes the physical demands of soccer players during small-sided games. Rev Bras Cineantropom Desempenho Hum 2015;17(3):269-79.

13. Bangsbo J. Yo-Yo Test. Copenhagen: HO Storm, 1996.

14. Fanchini M, Castagna, C, Coutts AJ, Schena F, Mccall A, Impellizzeri FM. Are the Yo-Yo intermittent recovery test levels 1 and 2 both useful? Reliability, responsiveness and interchangeability in young soccer players. J Sports Sci 2014;32(20):1950-7.

15. Krustrup P, Mohr M, Amstrup T, Rysgaard T, Johansen J, Steensberg A, Pedersen PK, Bangsbo J. The Yo-Yo Intermittent Recovery Test: physiological response, reliability, and validity. Med Sci Sports Exerc 2003;35(4):697-705.

16. Lizana CJR, Belozo F, Lourenço T, Brenzikofer R, Macedo DV, Shoitimisuta M, Scaglia AJ. Análise da potência aeróbia de futebolistas por meio de teste de campo e teste laboratorial. Rev Bras Med Esporte 2014;20(6):447-50.

17. Cohen J. Quantitative Methods in Psychology. Psychol Bull 1992;112(1):155-9.

18. Robinson G, O'Donoghue PG. A weghted kappa statistic for reliability testing in performance analysis of sport. Int J Perform Anal Sport 2007;7(11):12-9.

19. Beck TW. The importance of a priori sample size estimation in strength and conditioning research. J. Strength Cond Res 2013;27(8):2323-37.

20. Ferguson CJ. An effect size primer: A guide for clinicians and researchers. Prof Psychol Res Pract 2009;40(5):532-8.

21. Tabachnick B, Fidell L. Using multivariate statistics. 5th ed. New York: Harper \& Row, 2007.

22. Landis JR, Koch GC. The measurement of observer agreement for categorical data. Biometrics 1977;33(1):159-74.

23. David GK, Wilson RS. Cooperation improves success during intergroup competition: an analysis using data from professional soccer tournaments. PlosOne 2015; 10(8): e0136503.

24. Clemente FM, Martins FML, Mendes RS, Figueiredo AJ. A systemic overview of football game: the principles behind the game. J Hum Sport Exerc 2014;9(2):656-67. 
25. Gréhaigne JF, Godbut P, Bouthier D. Tactical knowledge in team sports from a constructivist and cognitivist perspective. Quest 1995;47(4):490-505.

\section{CORRESPONDING AUTHOR}

Gibson Moreira Praça Universidade Federal de Minas Gerais

Escola de Educação Física,

Fisioterapia e Terapia Ocupacional

Centro de Estudos em Cognição e Ação

Av. Pres. Antônio Carlos, 6627. Campus Pampulha.

CEP 31270-910. Belo Horizonte, Minas Gerais, Brasil.

E-mail: gibson_moreira@yahoo. com.br 